\title{
Accounting
}

\section{The effects of factors on making investment decisions among Omani working women}

\author{
Ansa Salim ${ }^{\mathrm{a}}$ and Sania Khan ${ }^{\mathrm{a}^{*}}$
}

\begin{tabular}{l}
${ }^{a}$ Assistant Professor, College of Business \\
\hline C H R O N I C L E \\
\hline Article history: \\
Received May 152020 \\
Received in revised format May \\
162020 \\
Accepted June 292020 \\
Available online \\
June 29 2020 \\
\hline Keywords: \\
Investment Behavior \\
Annual savings \\
Investment \\
Investment pattern \\
Working women \\
Salaried people \\
\hline
\end{tabular}

\section{Introduction}

In the twenty first century the investment attitude and the influencing behavior of people are really complicated. The majority of the people are very serious about their investment behavior as everybody likes to take pleasure in the benefits of what is earned through his/her efforts (Dang et al., 2019; Ghaeli, 2019). Enjoying the benefit of what one earns means utilization of the money in a wise and fruitful way (Salim, 2015). It also considers the investment for the long run. Lavishly spending the hardearned money is not a wise idea (Salim et al., 2016; Al-Nawafah \& Almarshad, 2020). The decisions about spending and investing are happening after a systematic process of different choice analysis. Saving and investment are definitely considered as a security for the long- term life. Most of the time, people go for saving the money and invest in banks and property which either gives a return or will enhance its value in the future (Hinkin, 1995). The people at different levels have different spending habits of investment (Sihotang et al., 2020). There are also uncertainties about future demands for the choice of savings and investment. Some uncertainties happen to life where people get into troubles like diseases and may lose their jobs. These hindrances may sometimes trigger them to behave proactively to save more. This study intends to understand the importance of motivational factors towards investment pattern of working women in North Governorate of Ash Sharqiyah region, Oman. This study also aims to analyze the demographic factors influencing the decision on saving and investment of working-class people in North Governorate of Ash Sharqiyah region, Oman.

* Corresponding author.

E-mail address: saniakhan05@gmail.com (S. Khan) 


\section{Literature Review}

The economic status of a country is based on the investments made by its citizens (Imtiaz et al., 2019; Lassoued et al., 2020; Truong et al., 2020). Sharma et al. (2014) found twenty-five key factors as the motivational factors which are useful on the investment decisions. The study also found that there was no relationship between the investment choices made by the people and their demography like education, job and years of experience. The same study also revealed that the first priority is given to Real estate and the last priority of investment was on 'Company Fixed Deposits'. The people of Oman are more conscious about the rumors affecting the industry on investment and not paying much attention to the amendments of law and government regulations. Salim and Raghavan (2017) in their study found that conscious efforts are made by the Omani women when they are doing something collectively especially in the north Ash Sharqiah region. Another study revealed that investment was like a game so the decision on investment is related to several psychological and emotional factors of an investor. So, the ultimate aim of an investor is to involve in a thoughtful investment based foreseen towards a high return on low risk investments. A study by Nofsinger (2008) found that people do not want to take risk at any point of life while carefully make their investments for the long run which reaps sufficient returns on their investment in future.

According to Salim et al. (2017) the long-term orientation of women in the rural area is bringing in lots of prosperity towards the society by uplifting the less privileged category of people to privileged category and it will result in the development of a country. Glogger (2008) identified risk and return as two major factors of investment. Warne (2012) enforces that investment behavior is directly connected with the stock market movements of serious investors. Parimalakanthi and Kumar (2015) found that majority of the respondents are more inclined to invest in banks as they believe it as the safe investment. Also, another interesting fact is that the more the education, the more the investment. This study suggests that investors definitely need to research on different ways of investment and its long-term benefit. Salim and Sulphy (2015) revealed the long-term orientation of women results in the long-term benefit and women empowerment as a whole.

Mathivannan and Selvakumar (2011) in their study found that the behavior of saving income among teachers is for their child's education and education. The demography and lifestyle of the respondents is influencing the saving habits of the teachers in playing a major role of investment behavior of teachers in the study area. According to Pandian and Thangadurai (2013) majority of the investors prefer to invest either in banks or in the form of gold. Accordingly, in a study by Chandra and Kumar (2012) the decision on investment is influenced by two major factors: one is exhaustive treatment and the other is objective treatment relating to the information which is available to the people and future information with scope. Salim (2015) states that the selffacilitated journey of long-term orientation that aims to women empowerment is a very important criterion for the attitude towards a nations progress. Several other studies in line with saving, investment and opportunities on investment in real estate, land, share market, gold, fixed deposit in banks and so on talk more about people with their long-term prospective thoughts. Salim et al. (2016) stated that long term orientation is another most important reason for the people to invest for uncertainty avoidance. The long-term orientation, self-efficacy and other behavioral aspects were found to have a relationship with investment patterns as a result of women empowerment. The research gap lies in understanding which factors determine the investment decision with reference to the various demographics of working women. Therefore, this study attempted to understand the importance of the awareness on investment options and relationship towards factors influencing investment options of salaried people in North Governorate Ash Sharqiyah region of Oman.

\section{Methodology and Methods}

The questionnaire consists of eleven questions with thirty-two sub questions. The questionnaire was translated into Arabic as the target respondents were Omani citizens. Magazines, newspapers, previous articles and journal from website were referred for the study to understand the current practices of Omani working women. Primary data from the survey was tabulated and analyzed. Below given tables provides an information on sample characteristics of the study. The main objective of this study is to find out the level of awareness and influencing factors. A structured questionnaire was developed based on the previous literature. The items on the questionnaire were divided among four major factors with sub factors. The inter-correlation was also performed to avoid the redundancy among the factors. To bring further clarity among the factors, Varimax rotation method was used to rotate the factors. This research also constructed and tested the survey tool using validity and reliability. Eight demographic questions and two major domains were identified through literature review which are Income distribution and Investment decisions. Sub- factors were identified in each individual domain and made as per sampling adequacy. Each sub factor was again rewritten based on the expert opinion. The experts were the academics with $\mathrm{PhD}$ from different Universities in Oman and also from the managerial level employees of different Banks. Then each item was thoroughly examined to avoid the duplication and confusion among the items in the questionnaire. After that 15 questions were found as the most valuable items for the study. Table 1 shows KMO and Bartlett's test and Table 2 provides the summary of total varimax explained. 
Table 1

KMO and Bartlett's Test

\begin{tabular}{ccc} 
Kaiser-Meyer-Olkin Measure of Sampling Adequacy. & .78 \\
& Approx. Chi-Square & 526.056 \\
Bartlett's Test of Sphericity & df & 91 \\
& Sig. & .000 \\
\hline
\end{tabular}

Source: Primary data analysis

Table 1 was used to measure sampling adequacy and it was found acceptable 0.78 . A value which is equal to 0.65 or greater can be used for doing factor analysis. The Varimax rotation was conducted to avoid the consideration of unwanted variables.

\section{Table 2}

Total Variance Explained

\begin{tabular}{|c|c|c|c|c|c|c|c|c|c|}
\hline \multirow[t]{2}{*}{ Component } & \multicolumn{3}{|c|}{ Initial Eigenvalues } & \multicolumn{3}{|c|}{ Extraction Sums of Squared Loadings } & \multicolumn{3}{|c|}{ Rotation Sums of Squared Loadings } \\
\hline & Total & $\%$ of Variance & Cumulative \% & Total & $\%$ of Variance & Cumulative $\%$ & Total & $\%$ of Variance & Cumulative $\%$ \\
\hline 1 & 3.801 & 34.557 & 34.557 & 3.801 & 34.557 & 34.557 & 2.696 & 24.508 & 24.508 \\
\hline 2 & 1.609 & 14.630 & 49.188 & 1.609 & 14.630 & 49.188 & 2.024 & 18.396 & 42.904 \\
\hline 3 & 1.220 & 13.093 & 62.321 & 1.220 & 13.093 & 62.281 & 1.911 & 17.377 & 60.281 \\
\hline 4 & .940 & 8.549 & 70.830 & & & & & & \\
\hline 5 & .817 & 7.425 & 77.255 & & & & & & \\
\hline 6 & .646 & 5.869 & 82.124 & & & & & & \\
\hline 7 & .602 & 5.469 & 87.593 & & & & & & \\
\hline 8 & .437 & 3.972 & 91.565 & & & & & & \\
\hline 9 & .373 & 3.395 & 94.960 & & & & & & \\
\hline 10 & .303 & 2.755 & 97.715 & & & & & & \\
\hline
\end{tabular}

Extraction Method: Principal Component Analysis

Source: Primary data analysis

Table 2 shows the first component with an Eigen value of 3.801 and cumulative percent $34.557 \%$ and second component with an Eigen value, 1.609 and the cumulative per cent of 49.188 per cent whereas the third component with an Eigen value of 1.220 accounts for 62.321 per cent of the total variability of the original variable. The result of Varimax rotation shows four variables on the first component and for the second component with three variables and finally three variables on the third component. This clearly explains a total variance of cumulative percent of $62.321 \%$.

Table 3

Rotated Component Matrix

\begin{tabular}{|c|c|c|c|}
\hline & \multicolumn{3}{|c|}{ Component } \\
\hline & 1 & 2 & 3 \\
\hline Q1 & & & .568 \\
\hline Q2 & & .766 & \\
\hline Q3 & & .656 & \\
\hline Q4 & & .894 & \\
\hline Q5 & & & \\
\hline Q6 & & & .795 \\
\hline Q7 & & & .876 \\
\hline Q8 & .667 & & \\
\hline Q9 & .799 & & \\
\hline Q10 & .704 & & \\
\hline Q11 & .787 & & \\
\hline
\end{tabular}

Source: Results from Primary data analysis

Extraction Method: Principal Component Analysis

Rotation Method: Varimax with Kaiser Normalization

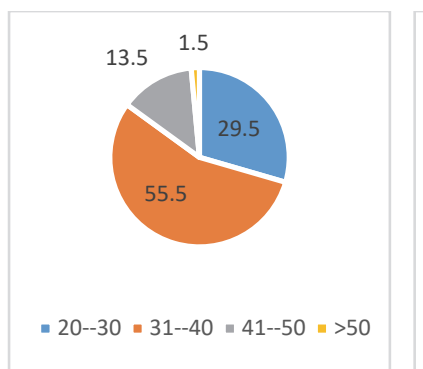

Age

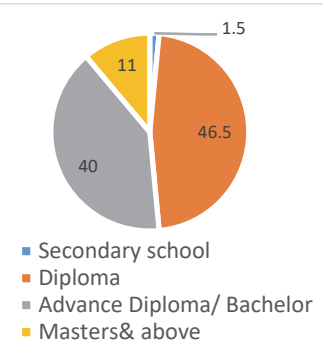

Educational background

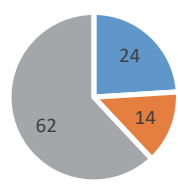

- Married without kids

- Not-married

- Married with kids

Marital status

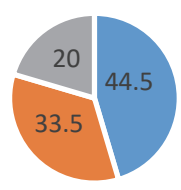

$=<3 \quad$ - $4--6=6$

Family size 
660

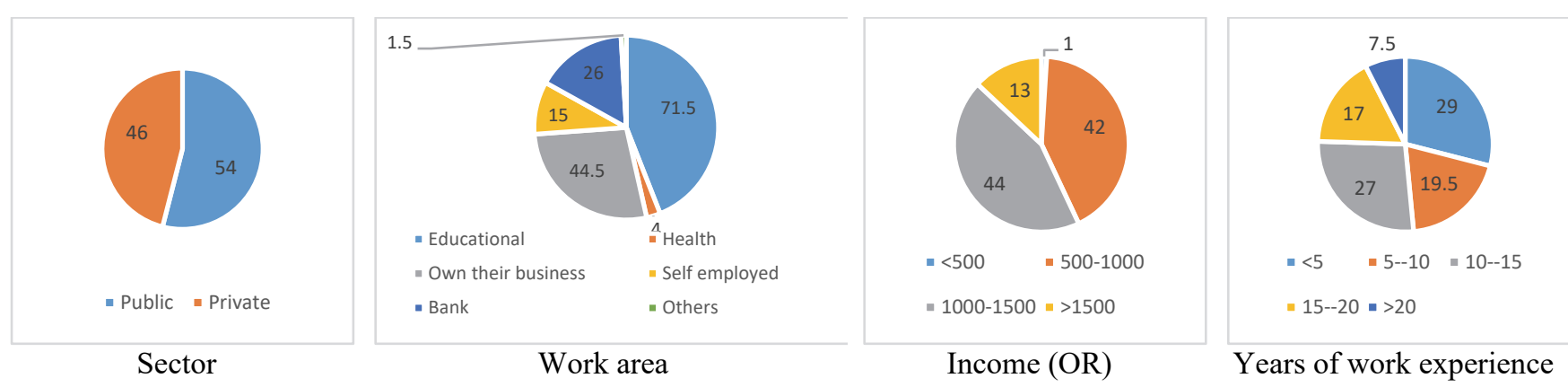

Fig. 1. Personal characteristics of the participant

Fig. 1 presents personal characteristics of the participants. According to our survey, out of 200 sample respondents in our research $29.5 \%$ are fall under the age group of 20-30 years, 55.5\% are between $31-40$ years' age, $13.5 \%$ are $41-50$ years and $1.5 \%$ are above 50 years. This represents majority of respondents are in their mid-age group between $31-40$ years and are in the age to save their income. The figure also shows that out of 200 sample respondents in our research $14 \%$ are not married, $24 \%$ are married without kids and 62\% married with kids. Moreover, out of 200 sample respondents in our research $44.5 \%$ represent family which has up to 3 members, $35.5 \%$ that represent family which has 4-6 members, and $20 \%$ responded represent family which has above 6 members. The results indicate that 54\% work in public sector and $46 \%$ work in private firms. In addition, in terms of years of job experience, $29 \%$ were below 5 years, and $19.5 \%$ hold $5-10,27 \%$ had $10-15,17 \%$ possess $15-20$ and $7.5 \%$ had above 20 years of experience. The results also depict that out of 200 sample respondents in our research $1 \%$ made a monthly income of up to RO.500, 42\% earned RO.500-1000, 44\% earned RO.1000-1500, and 13\% received RO.1500. Our survey results also indicate that out of 200 sample respondents in our research $71.5 \%$ worked in educational sector, 4\% in health industry, $44.5 \%$ worked for on their own business, $15 \%$ were self-employed and $26 \%$ worked in bank and $1.5 \%$ employed with others. Table 4 also shows the percentage of the unutilized income of the respondents.

Table 4

Percentage of Unutilized income of the respondents

\begin{tabular}{ccc}
\hline Percentage of Income & Respondents & \% of respondents \\
\hline $0 \%$ & 18 & 9 \\
$0-10 \%$ & 33 & 16.5 \\
$10-20 \%$ & 59 & 29.5 \\
$20-30 \%$ & 52 & 26 \\
Above $40 \%$ & 9 & 4.5 \\
Others & 0 & 0 \\
\hline Total & $\mathbf{2 0 0}$ & $\mathbf{1 0 0}$ \\
\hline
\end{tabular}

Source: Primary data analysis

It is evident from Table 5 that 78 (39\%) of the respondent states that they invest monthly for doing the construction business. $167(83.5 \%)$ of the respondent states that they invest monthly in Jamiyah (a form of small investment scheme informally made by different women groups in the rural areas of Oman), 38 (19\%) and $36(18 \%)$ respondents state that that they invest in Real estate for living and Real estate for earning respectively on a Quarterly basis. 93 (43.5\%) of the respondents state that they never invested in Real Estate for Living and 96 (48\%) of the respondents state that they never invested in Real Estate for Earning. 120 respondents $(60 \%)$ states that they never invested in Shares and Securities. 33 respondents, i.e., $(16.5 \%)$ respondents state that they invest their income in Fixed Saving on a Quarterly basis. At the same time another 23 respondents (11.5\%) of respondents state that they prefer to invest in fixed deposit on a half yearly basis.

Table 5

Investment of the respondents $(\mathrm{N}=200)$

\begin{tabular}{|c|c|c|c|c|c|c|c|}
\hline$\%$ of Invest & $\begin{array}{l}\text { Construction } \\
\text { business }\end{array}$ & $\begin{array}{l}\text { Real estate for } \\
\text { living }\end{array}$ & $\begin{array}{l}\text { Real estate for } \\
\text { earning }\end{array}$ & Jamiyah & $\begin{array}{c}\text { Shares/ } \\
\text { Securities }\end{array}$ & $\begin{array}{l}\text { Own small } \\
\text { business }\end{array}$ & Fixed saving \\
\hline Monthly & 78 & 24 & 28 & 167 & 15 & 58 & 19 \\
\hline Quarterly & 8 & 38 & 36 & 7 & 23 & 29 & 33 \\
\hline Half year & 3 & 14 & 9 & 4 & 15 & 8 & 23 \\
\hline Yearly & 9 & 11 & 5 & 3 & 6 & 2 & 7 \\
\hline As and when desired & 28 & 20 & 26 & 2 & 21 & 19 & 20 \\
\hline Not at all & 74 & 93 & 96 & 17 & 120 & 84 & 98 \\
\hline Total & 200 & & & & & & \\
\hline
\end{tabular}

Source: Primary data analysis 
Table 6

Influence on Investment decisions of the respondents $(\mathrm{N}=200)$

\begin{tabular}{|c|c|c|c|c|c|}
\hline & Family member & No one & Professional association & Friends or Colleagues & Expert opinion \\
\hline To a great extent & 122 & 53 & 84 & 70 & 75 \\
\hline To some extent & 46 & 98 & 67 & 71 & 50 \\
\hline To a moderate level & 25 & 31 & 36 & 46 & 48 \\
\hline To an insignificant level & 7 & 18 & 13 & 13 & 27 \\
\hline Total & 200 & & & & \\
\hline
\end{tabular}

Source: Primary data analysis

From the results of Table 6,122 respondents $(61 \%)$ believe that, to a great extent, the family members are responsible for the major influence on their investment decision. 84 respondents (42\%) got influenced by Professional Association and 75 (37.5\%) respondents got influenced on expert opinion to a great extent the family members are the major influence on their investment decision. In addition, 71 respondents $(35 \%)$ believe that they got influenced by Friends or Colleagues to some extent.

Table 7

Evaluate statements of the respondents

\begin{tabular}{|c|c|c|c|}
\hline & Statements & Respondents & $\%$ \\
\hline 1 & The information related to various investment options easily available. & 25 (Strongly Agree) & 12.5 \\
\hline 2 & I can avail guidance from institutions related to investment. & 30 (Agree) & 15 \\
\hline 3 & Unutilized savings is necessary for unpredictable future. & 45 (Agree) & 22.5 \\
\hline 4 & It is necessary to create awareness about savings and investment to next generation & 40 (Strongly Agree) & 20 \\
\hline 5 & Investment and saving plan help in meeting financial goals & 25 (Strongly Agree) & 12.5 \\
\hline \multirow[t]{2}{*}{6} & I am aware of the different features of various investments. & 35 (Strongly Agree) & 17.5 \\
\hline & Total & 200 & 100 \\
\hline
\end{tabular}

Source: Primary data analysis

Table 7 summarizes the statements of respondents. Majority of respondents (87\%) were interested in getting guidance from institutions related to their investment plans, $85 \%$ stated they were aware of different features of investment and the information on various investment options which were easily available for them. $82 \%$ of respondents reported unutilized savings were necessary for unpredictable future and $81 \%$ stated it is mandatory to create awareness about savings and investment to the next generation and $80 \%$ believed investment and saving plan help them meet their future financial goals. Table 8 presents the results of ANOVA test between family size and their monthly income. The results show that there were some statistically meaningful differences between educational background and unutilized money with their investment plan. Table 9 presents the results of ANOVA test between occupation and income.

\section{Table 8}

ANOVA based on Family Size and distribution of monthly income

\begin{tabular}{lll}
\hline Items & F & Sig. \\
\hline Educational Purpose & 8.783 & .000 \\
Utilities & 2.650 & .073 \\
Jamiyah & 5.812 & .004 \\
Loan & 4.281 & .015 \\
Fixed Savings & 1.085 & .340 \\
Shares/Securities & .948 & .389 \\
Unutilized Money & 4.884 & .009 \\
Other Investment & .899 & .409 \\
Percentage of your income which is unutilized & .361 & .697 \\
\hline Sol Pre
\end{tabular}

Source: Primary data analysis

\section{Table 9}

ANOVA based on Occupation and distribution of monthly income

\begin{tabular}{|c|c|c|}
\hline Item & $\mathbf{F}$ & Sig. \\
\hline Educational Purpose & 1.241 & .267 \\
\hline Utilities & .051 & .821 \\
\hline Jamiyah & .352 & .554 \\
\hline Loan & .084 & .772 \\
\hline Fixed Savings & 1.435 & .232 \\
\hline Shares/Securities & .000 & .998 \\
\hline Unutilized Money & 2.282 & .132 \\
\hline Other Investment & 8.281 & .004 \\
\hline Percentage of your income which is unutilized & 2.100 & .149 \\
\hline
\end{tabular}

Source: Primary data analysis 
From the results of Table 9, it is clear that there exists statistically significant difference in the distribution of monthly income towards other investments based on occupation. where all other items remain same with no statistically significant differences.

Table 10

ANOVA based on Income and distribution of monthly income

\begin{tabular}{|c|c|c|}
\hline Items & $\mathbf{F}$ & Sig. \\
\hline Educational Purpose & 4.100 & .008 \\
\hline Utilities & 1.635 & .183 \\
\hline Jamiyah & 5.338 & .001 \\
\hline Loan & 4.938 & .003 \\
\hline Fixed Savings & .628 & .598 \\
\hline Shares/Securities & .429 & .732 \\
\hline Unutilized Money & 3.658 & .013 \\
\hline Other Investment & 5.301 & .002 \\
\hline
\end{tabular}

Source: Primary data analysis

According to the results of Table 10, it is clear that there exists statistically significant difference in the distribution of monthly income towards educational purpose, Jamiyah, Loan Unutilized money and other investments based on Income. where all other items remain same with no statistically significant differences.

\section{Findings}

All the respondents were the female and the average age i.e. (55.5\% of respondents) were between $31-40$ years. The respondents of this study have clearly stated that the majority of their investment was influenced by the family members and professional associations they were connected with. It is an insight for the future researchers and policy makers to develop better awareness by making formal bodies to help the working women understand about the avenues on modern investment. Most of the respondents prefer the Jamiyah as their best investment. This shows there exists a lack of awareness associated with the Mutual fund, shares etc. which are also the best options of investment plans. Therefore, it is suggested for them to get exposed on some knowledge related to banking investment plans. In order to attract more savings, people are suggested to attend training classes to improve their saving patterns by offering more return on investment. Financial authorities should arrange awareness classes relating to saving habits and investment in order to develop the economic status of the individuals. The present study has covered only North Ash Sharqiyah Governorate of Oman. It is not advisable to generalize the result of this research to other regions or nations. It is further recommended to conduct cross national studies to understand the investment plans and behavior of the working women.

\section{Conclusions}

Nowadays, people rely on the information that are available on internet and from the consultation of their colleagues and close friends. Due to changing in living style and survival requirements of the society, the people are wisely investing their income for further wealth generation. Subsequently, the people in the Middle East are more aware of change in economic status of nation's wealth they evade spending more than their income level especially on expensive products. Foreseeing the future requirements is very evident from the study with regard to the children education, safety and financial security for the future. This paper has contributed the behavioral patterns and motivational factor towards the influence of saving behavior in North A'Sharqiyah region of Oman. The study has also provided a deep insight towards the methods of investment among working class women who will be the backbone for a family and the society as a whole.

The study also has demonstrated the thought process and fear towards certain investment attitude which very well suites with the betterment of a neglected community in the past. From the study, it is evident that majority of the investors are more inclined to invest in Jamiyah followed by Gold, Silver and fixed deposits. Also, another interesting fact which is revealed from the study is that the women in the new generation were not interested in real estate. Still there is an ample scope for further development in understanding prevailing investment in the country. The most important motivating factors were family members and Professional Associations. Therefore, it is recommended to give workshops, seminars and conferences for the working women to create more awareness and investment practices which would become a powerful tool to flourish in terms of economic status. They should be motivated and educated to save the surplus of their income for their future and for the nation. It will boost up the economy. The significance of this study points to the perspectives of working women towards investment in different sectors of Oman, North A'Sharqiyah region based on the economic status, education level and literacy in technology. 
The authors are grateful to all the Delphi panel experts for sharing their opinions and valuable suggestions in developing the research model with a qualitative approach and for making this study possible.

\section{References}

Al-Nawafah, S., \& Almarshad, M. (2020). The role of decentralization for balancing employee performance in governmental universities in Jordan. Management Science Letters, 10(14), 3217-3224.

Chandra, A., \& Kumar, R. (2012). Factors influencing Indian individual investor behaviour: survey evidence. Electronic Journal, 39(3), 141-167.

Dang, T., Phan, T., Tran, V., Tran, T., \& Pham, T. (2019). The impact of accounting disclosures on individual investors' decision making in Vietnam Stock Market. Management Science Letters, 9(13), 2391-2402.

Ghaeli, M. (2019). The role of gender in corporate governance: A state-of-art review. Accounting, 5(1), 31-34.

Glogger M. (2008), Risk and Return. Adapted from: http://university.akelius.de/library/pdf/risk_and_return_martin_glogger.pdf

Hinkin, T. (1995). A review of scale development practices in the study of organizations. Journal of Management, 21(5), 967988.

Lassoued, K., Awad, A., \& Guirat, R. (2020). The impact of managerial empowerment on problem solving and decision making skills: the case of Abu Dhabi University. Management Science Letters, 10(4), 769-780.

Imtiaz, R., Kazmi, S., Amjad, M., \& Aziz, A. (2019). The impact of social network marketing on consumer purchase intention in Pakistan: A study on female apparel. Management Science Letters, 9(7), 1093-1104.

Malhorta, (2009). A. Stock Investment Decision Making. Adapted from: http://ezinearticles.com/?Stock-InvestmentDecision-Making\&id=2300895

Mathivannan, S., \& Selvakumar, M. (2011). Saving and investment pattern of school teaches-A study with reference to Sivakasi Taluk, Tamil Nadu. Indian journal of Finance, 5(4), 12-26.

Nofsinger J. (2008). The Psychology of Investing. $3^{\text {rd }}$ ed. Pearson Education Limited.

Parimalakanthi, K., \& Kumar, M. A. (2015). A Study on Investment Preference and behaviour of Individual Investors in Coimbatore City. Bonfring International Journal of Industrial Engineering and Management Science, 5(4), 170.

Pandian, V. A., \& Thangadurai, G. (2013). A study of investors preference towards various investments avenues in Dehradun district. International Journal of Management and Social Sciences Research (IJMSSR), 2(4), 22-31.

Salim, A., \& Raghavan, J. (2017). Collectivistic approach of Omani women in banking sector with special reference to north A'sharqiah region, Oman. Ahead International Journal of Recent Research Review (AIJRRR), 1(11).

Salim, A., Sulphey, M. M., \& Thilagar, P. (2017). A study on the relationship between long-term orientation, self-efficacy and certain behavioral aspects of women micro-entrepreneurs. Journal of Advanced Research in Dynamical and Control Systems, 9(12), 764-784.

Salim, M. A., \& Sulphy, M. M. (2015). A study on Long-term orientation, Self-Efficacy and Self-derogation of Kudumbashree members with special reference to Self Help Group in Kerala. International Journal of scientific research and management (IJSRM), 3(8), 3469-3473.

Salim, A. (2015). Women empowerment through long term orientation with special reference to SHG, Kerla Region. International Journal of Science and Research (IJSR), 5(16), 1462-1464.

Salim, A. S., Al Jahdhami, M. A. H., \& Al Handhali, S. N. S. A. (2016). A study on Customer preferences towards selected local Omani (FMCG) products. International Journal of Science and Research (IJSR), 6(4), 1273-1277.

Sharma, R.K., Goyal, R.S., \& Anil, (2014). Study of factors influencing investment decision of households in Oman, 2nd International Conference on Technological and Management Advances in the New Age Economy: An Industry Perspective.

Sihotang, J., Puspokusumo, R. A. A. W., Sun, Y., \& Munandar, D. (2020). Core competencies of women entrepreneur in building superior online business performance in Indonesia. Management Science Letters, 10(7), 1607-1612.

Truong, D., Giao, N., \& Ly, L. (2020). Factors affecting the role of women in the economic development of rural household families in Vietnam: A case study in Trieu Son district Thanh Hoa province. Accounting, 6(3), 267-272.

Warne, D. P. (2012). Investment behavior of individual investor in stock market. International Journal of Research in Finance \& Marketing, 2(2), 243-250. 
(C) 2020 by the authors; licensee Growing Science, Canada. This is an open access article distributed under the terms and conditions of the Creative Commons Attribution (CC-BY) license (http://creativecommons.org/licenses/by/4.0/). 